\title{
A SURVEY OF MATLAB EFFICIENCY IN DAMAGE DETECTION IN CONCRETE GRAVITY DAMS
}

\author{
SAJAd Esmaielzade ${ }^{1}$, Hassan AHMadi ${ }^{2 *}$ AND Seyed AbBas Hosseini ${ }^{1}$ \\ ${ }^{1}$ Department of Civil Engineering, Science and Research Branch, \\ Islamic Azad University, Tehran, Iran. \\ ${ }^{2}$ Department of Civil Engineering, Roodehen Branch, \\ Islamic Azad University, Tehran, Iran. \\ *Corresponding author: hgahmadi@riau.ac.ir
}

(Received: $12^{\text {th }}$ July 2018; Accepted: $15^{\text {th }}$ April 2019; Published on-line: $1^{\text {st }}$ June 2019)

https://doi.org/10.31436/iiumej.v20i1.970

\begin{abstract}
Detection of damage in concrete gravity dams (CGDs) is one of the challenges that need to be overcome since dam failure may lead to irreversible consequences. This research aims to detect structural damage within CGDs by wavelet analysis. From a structural point of view, stiffness is an important factor in the dynamic behaviour of concrete gravity dam systems. Any sudden change in the stiffness leads to alteration in the dynamic response of the structures. The proposed analysis of such a condition will help to investigate the responses before and after the occurrence of any structural damage. The main contributions of this paper are to detect the existence of any damage in the dam structure and determine the damage location along the height of the dam. In order to achieve these purposes, three finite element models of the Pine Flat, Bluestone, and Folsom dams are chosen as case studies. These dams have been modelled for both intact and damaged states, and their geometrical, physical, and mechanical characteristics are defined by SAP2000 software. A series of modal analyses was performed to determine the frequencies and shapes of the structural motions. After reduction of the elasticity modulus by $20 \%$ and $50 \%$, the Discrete Wavelet Transform (DWT) was applied to the difference between the intact and damaged observations. Then, the DWT outputs were analysed to get information about the existence of damage as well as its location in the dam structure. Overall, from the obtained results, the main finding of this study states that the location and severity of the structural damages have been efficiently detected according to the significant amplitude variations in DWT diagrams.
\end{abstract}

ABSTRAK: Pengesanan kerosakan pada empangan graviti konkrit (CGDs) adalah salah satu cabaran yang perlu diatasi disebabkan kegagalan empangan yang boleh membawa kepada akibat buruk. Kajian ini bertujuan bagi mengesan kerosakan struktur dalam CGDs menggunakan analisis wavelet. Dari sudut pandang struktur, struktur yang kukuh adalah faktor penting dalam sifat dinamik sistem empangan graviti konkrit. Sebarang perubahan secara tiba-tiba pada struktur bangunan membawa kepada perubahan tindak balas dinamik struktur. Analisis yang dicadangkan terhadap keadaan ini membantu dalam memberi tindak balas sebelum dan selepas jika berlaku sebarang kerosakan struktur. Sumbangan utama kajian ini adalah bagi mengesan jika terdapat sebarang kerosakan pada struktur dalam empangan dan menentukan lokasi kerosakan sepanjang ketinggian empangan. Bagi mencapai matlamat ini, tiga model unsur terhingga daripada empangan Pine Flat, Bluestone dan Folsom telah dipilih sebagai kes kajian. Kesemua empangan ini dimodelkan bagi kedua-dua keadaan iaitu ketika baik dan rosak. Ciri geometri, 
fizikal dan ciri-ciri mekanikal juga telah ditakrif menggunakan perisian SAP2000. Satu siri model analisis telah dijalankan bagi menentukan frekuensi dan bentuk gerakan struktur. Selepas pengurangan modulus keanjalan sebanyak 20\% dan 50\%, Transformasi Wavelet Diskret (DWT) telah digunakan bagi mengesan perbezaan antara keadaan baik dan rosak. Kemudian, hasil dari DWT ini dianalisis bagi mendapatkan maklumat mengenai kewujudan kerosakan pada empangan dan juga lokasi kerosakan dalam struktur empangan. Secara keseluruhan, hasil kajian berjaya menentukan lokasi dan tahap kerosakan struktur dengan cekap mengikut variasi amplitud ketara dalam rajah DWT.

KEYWORDS: concrete gravity dams; frequency analysis; failure; wavelet analysis; SAP2000

\section{INTRODUCTION}

Among all engineering structures, dams are important and strategic resources for any government. These constructions, like all the other engineering structures, always have the possibility of failure during their lifetime and this will intensify with increasing operational life and environmental effects, such as earthquakes. For example, minute faults inside the structure, if not diagnosed in a timely manner, might affect the whole body of a system and would lead to structure collapse which might create a significant loss of property and even human life [1].

Refer to the work done by Aldemir et al. who investigated the dynamic responses of the Melen Dam using a 1:75 scale model. They studied the damage propagation, sliding displacement, and stability of dams, showing that there is a good agreement between experimental and analytical results. To be more precise, in spite of the fact that there was major cracking at the base of the monolith, no noticeable sliding or problem that could jeopardize the stability of the dam was observed [2].

Alembagheri and Ghaemian studied the damage assessment of a concrete arch dam (the Morrow Point Dam) through nonlinear IDA, which included the dam-foundation interaction. The conducted study introduced two damage indices based on Maximum Crest Displacement (DIU) and Damage Energy Dissipation (DIE). They showed that the proposed damage indices could properly assess damage in dams [3].

A key problem in SHM involves performing damage detection and isolation from a set of measured data. Typically, the number of sensors used to collect the required data is limited due to available funds, equipment, and accessibility [4]. In this case, Lian et al. studied the optimal sensor placement for large structures using the nearest neighbour index and a hybrid swarm intelligence algorithm [5].

Pirboudaghi et al. have proposed a procedure identification of cracks in concrete dams using a combination of the extended finite element method (XFEM) according to cohesive crack segments (XFEM-COH) and continuous wavelet transform (CWT). The results showed that the coupled procedure had great capability for the online SHM of concrete dams. Furthermore, any small change in the system was discernible when the final crack profile and simulation of the dam body under strong seismic excitations had been achieved. [6].

Ambient modal identification based on the non-stationary correlation technique in 2016 was investigated by Lin [7]. Generally, in this paper, it was recommended that if ambient excitation could be represented by a product model with a slow, time-varying function, without any additional transformation of the original non-stationary responses, they could be treated approximately as a stationary random process; then, the non- 
stationary cross-correlation functions of structural responses were evaluated at arbitrary, fixed time moments. As a result, they had a mathematical form similar to that of the free vibration of a structure, from which modal parameters of the original system could thus be identified [7]. Modal analysis, as a non-destructive and efficient test, presents valuable information for maintenance and economic decision-making with regard to infrastructures, such as dams [8].

Sun and Ren studied the Koyna concrete gravity dam using time-frequency localization performance of the wavelet transform and demonstrated the distribution features of wavelet energy for the dam dynamic response signals under seismic conditions with various amplitudes. They concluded that wavelet energy was accumulated in the lowfrequency range by increasing the amplitude. They simulated an earthquake with moderate intensity and analysed its residual seismic bearing capacity. A damage index was proposed in this context and the overall degree of damage in the dam was determined via defined formula under the simulated earthquake [9].

Generally, the investigations done on modal analysis with regard to dams have not been that extensive, but the comparison of coupled and uncoupled modals in vibrational analysis of concrete gravity dams in the time domain by Samii and Lotfi [10] and the vibrational analysis of dam-reservoir systems by Calayir et al. can be considered [11].

With the advance of design and manufacturing technology of complicated parts, a necessity for a reduction of cost and time and also for responding to industrial needs arises. Therefore, the finite element method is applied for the solution of various engineering problems in stable, unsteady, linear or nonlinear situations. From among finite element method software, SAP2000 has been recognized as an accurate research and practical program in industries and universities due to its computational precision, [12] ease of access and understanding of function, capability in assembling different parts in a separate environment, facility of contact between surfaces, and the possibility of dynamic loading analysis (e.g. earthquakes and water waves) on various structures [12].

Pirboudaghei et al. simulated the Karun 3 dam through numerical modelling and analysis via the finite element method (FEM) and XFEM-based cohesive crack parts, sequentially. The dam was also assessed under earthquake excitation. Results revealed the proper ability of the recommended procedure, despite difficulties of the input effect and modal interference. The physical differences in the structure, cracking initiation time from the evaluation of the time-frequency window of the structure response, the exact location of the crack from a comparison of the intact and damaged crest and central cantilever vibration modes were made possible by this method [13].

Kourehli introduced an innovative method for damage detection using expanded mode shapes and extreme learning machine (ELM). The method used the first two expanded mode shapes and natural frequencies as the input parameters and damage conditions as output to instruct the ELM model. Moreover, the noise effect on the measured modal data was surveyed. This approach was applied to three cases, including a four-span continuous beam, plane steel truss, and four-story plane frame. The results showed the accuracy and effectiveness of the offered approach using incomplete modal data. Also, he indicated in the article that this method was an appropriate process for damage detection despite utilizing noisy modal data [14].

By a general review of the aforementioned context, it can be seen that detecting structural damage is mainly investigated on simple structural systems, like multi-story building frames, trusses, etc. In other words, concrete gravity dams, due to their high 
degrees of freedom and complex geometry, are rarely studied in the literature. Hence, the current study aims to employ wavelet analysis for identification of damages within such superstructures. It seems that there are not similar researches in the field of modal analysis of concrete gravity dams with a reduction of the elasticity modulus in some elements and damage detection with wavelet analysis.

\section{FINITE ELEMENT MODELING WITH SAP2000}

It should be noted that not much attention has been paid to the detection of existing damage based on wavelet analysis in a significant superstructure like a dam. Three wellknown concrete gravity dams, namely the Pine Flat, Bluestone, and Folsom (Fig. 1), have been modelled in both damaged, which is simulated for these dams, and intact states through geometrical, physical, and mechanical characteristics by SAP2000 Finite Element software. The results are shown in Section 4. Generally, this research can be characterized as follows:

- Modelling of the dam and damage

- Meshing

- Obtaining dam response from the modal data

- Selecting the type of analysis, setting the parameters and doing the analysis

- Doing wavelet analysis on the data

- Investigating the possibility of damage detection in intact and damaged dams

- Comparing and obtaining the results

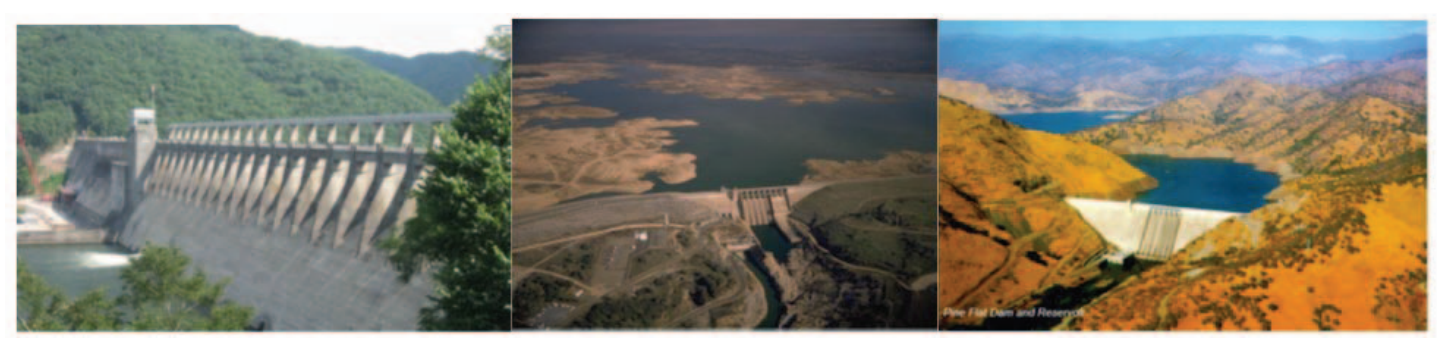

Fig. 1: A view of the CGD selected for modelling: the Bluestone Dam (Left); the Folsom Dam (Middle); Pine Flat Dam (Right) [15].

The Bluestone Dam is located just upstream of the confluence of the New and Greenbrier Rivers, near Hinton in West Virginia, USA and was designed in the late 1930s as a combined flood control and hydroelectric power facility [16]. The elevation of the dam base at the lowest point is $415 \mathrm{~m}$ and the elevation at the top of the non-overflow sections is $468 \mathrm{~m}$, making the maximum height of the non-overflow section of this dam about $53 \mathrm{~m}$ [17]. The Folsom Dam was built by US Army engineers in Sacramento, California. The reservoir volume of the lake is about 1205 million cubic meters. The purpose of this dam is to control flooding and provide drinking water and electricity as well. To analyse the dam, the tallest monolith, (Block No. 11), with an elevation of about $82.5 \mathrm{~m}$ is used. The Pine Flat is a concrete gravity dam on the Kings River in the United States. The height of the dam is about $130 \mathrm{~m}$ and its primary purpose is to control flooding with irrigation, power generation, and recreation being secondary in importance $[15,18]$.

By neglecting the material nonlinearity effects and assuming linear behaviour, the mechanical properties of the mass concrete, which are supposed the same in both static and dynamic cases, are given in Table 1. 
Table 1: Material Properties of the Pine Flat, Bluestone, and Folsom Dams [19]

\begin{tabular}{ccccc}
\hline Quantity & Unit & Pine Flat & Bluestone & Folsom \\
\hline Density of Concrete & $\mathrm{kg} / \mathrm{m}^{3}$ & 2483 & 2483 & 2579 \\
Modulus of Elasticity & $\mathrm{GPa}$ & 33.558 & 33.558 & 40.68 \\
Poisson's Ratio & - & 0.255 & 0.255 & 0.19 \\
\hline
\end{tabular}

Moreover, the following assumptions have been made in the modelling of the damreservoir interaction:

- A rectangular shape is assumed for the reservoir, with a length three times the height of the dam (as recommended in [20]);

- The free-board in the lake is neglected in order to model the interaction between the dam and the reservoir easily; i.e. the water level is equal to the height of the dam;

- Dam-water interaction is modelled as the tie type, where the nodes are constrained together on the interface of the two media [21];

- The transmitting boundary condition is assigned to the truncated far-end of the reservoir so that the pressure waves are not reflected back into the reservoir [21];

- Zero hydrodynamic pressure is assigned to the free surface of the reservoir and there is no absorbing boundary condition at the bottom of the reservoir [18];

- The bulk modulus of water is: $K_{w}=2.2 \mathrm{GPa}$;

- The density of water is: $\rho_{w}=1000 \mathrm{~kg} / \mathrm{m}^{3}$

Finally, in modelling the dam-foundation interaction, it is assumed that:

- The foundation is rigid;

- Sliding along the dam-foundation interface will not occur;

- Uplift pressure is not modelled in this study.

Here, according to the assumptions made in the previous section, three 2D Finite Element models of concrete gravity dams are constructed, as shown in Fig. 2. According to Fig. 2, using an automatic mesh generation procedure, the Finite Element meshes are made by plane-stress four-node elements.

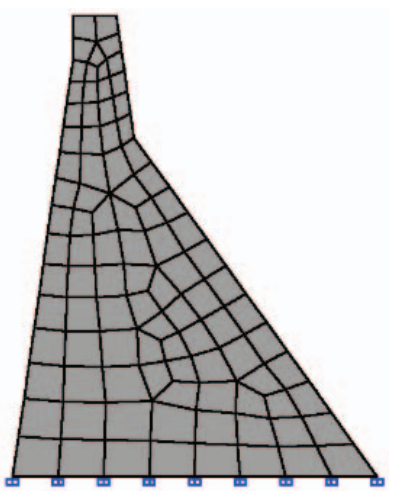

Bluestone

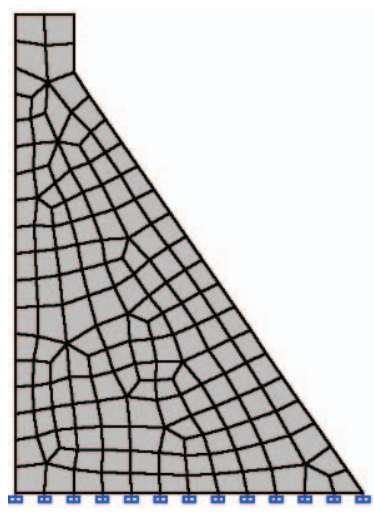

Folsom

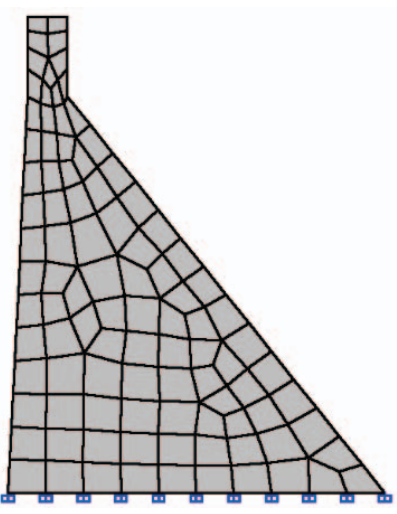

Pine Flat

Fig. 2. The Configuration of Finite Element Models Considered for the Bluestone, Folsom, and Pine Flat Dams (not to scale). 
In order to do the analyses, the bodies of the dam are considered with their mechanical characteristics for the intact (Fig. 2) and damaged states (Figs. 3-8). They are modelled by SAP2000 and have undergone frequency analysis in the frequency band 0100. The amount of damage in the form of the elasticity modulus reduction is illustrated in the following, based on different scenarios in various locations in the Pine Flat, Bluestone and Folsom dams.

To study the dynamic behaviour of the dams, the vibration frequency of the modes should initially be computed so that the structure damping can be calculated based on Rayleigh, or frequency-dependent damping. The system damping is achieved based on Eq. (1) through a linear combination from the mass and stiffness matrix. The coefficients of this linear combination are computed from the frequency modes of the dams:

$$
C=\alpha M+\beta K
$$

where $C$ is the damping coefficient; $M$ is mass and $K$ is stiffness. $\alpha$ and $\beta$ are Rayleigh linear combination coefficients, which are obtained through Eq. (2) and (3):

$$
\begin{aligned}
& \alpha=\frac{2 \xi \omega_{i} \omega_{j}}{\omega_{i}+\omega_{j}} \\
& \beta=2 \xi /\left(\omega_{i}+\omega_{j}\right)
\end{aligned}
$$

In the above equations, $\xi$ is the damping ratio which is assumed $5 \%$ in frequency analysis. $\omega_{i}$ and $\omega_{j}$ are the angular frequencies of the two modes from the vibrational modes. In the Pine Flat, Bluestone and Folsom analyses, the Rayleigh damping coefficients are computed from the first and third frequencies of the dams' vibrational modes with a damping ratio of $5 \%$ [22].

The damping coefficients of the dams, which are needed in the dynamic analysis, are computed by frequency. The amounts of frequencies for the first four vibrational modes of the intact and damaged cases are shown in Table 2. The dams' responses obtained from frequency analysis were investigated and it was seen that the frequencies in the damaged cases were reduced. In the following figures and tables, the Pine Flat, Bluestone, and Folsom dams are presented in different locations of damage and different damage severity with their corresponding coefficients. Damage is made through the elasticity modulus reduction by $20 \%$ and $50 \%$ of the original amount in the elements shown below. The elasticity modulus is a quantity that measures an object or substance's resistance to being deformed elastically when a stress is applied to it. In addition, $X$ is the horizontal axis and $Z$ is the vertical one in the following figures. The locations of damage are shown with blue squares. In addition, for each scenario based on the damage severity, two different cases have been considered including 50\% and $20 \%$ reduction of elasticity modulus.

\subsection{Schematics of the Pine Flat Dam Scenarios:}

In the Pine Flat Dam, the damage is shown in the form of $50 \%$ and $20 \%$ reduction of concrete elasticity modulus in two areas with predetermined X and Z (in SAP2000, Z indicates the vertical axis). These locations are shown by a square in the following figures. 


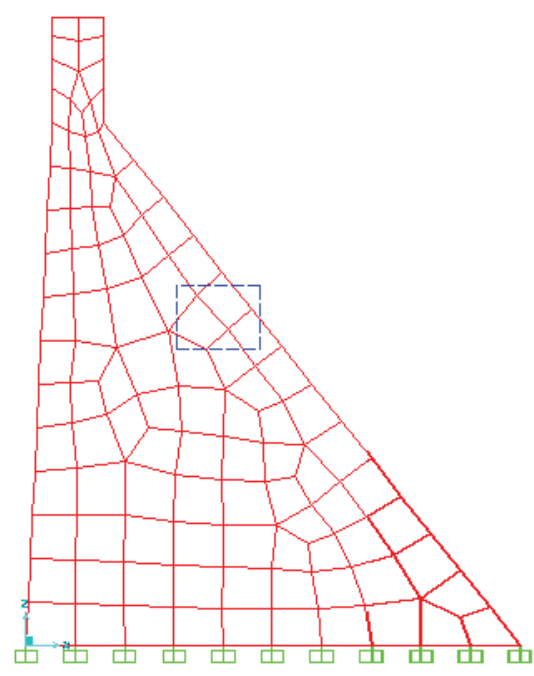

Fig. 3 : $Z=63 \mathrm{~m}, X=36 \mathrm{~m}$, damage severity $50 \%$ (not to scale).

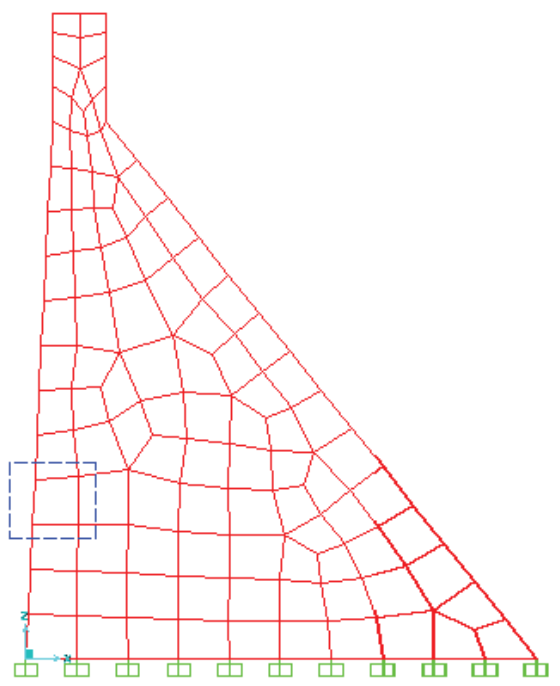

Fig. $4: \mathrm{Z}=30 \mathrm{~m}, \mathrm{X}=1.5 \mathrm{~m}$, damage severity $20 \%$ (not to scale).

\subsection{Schematics of the Bluestone Dam Scenarios:}

In the Bluestone Dam, the damage is shown in the form of $50 \%$ and $20 \%$ reduction of concrete elasticity modulus in two areas with predetermined X and Z (In SAP2000, Z indicates the vertical axis). These locations are shown by a square in the following figures.

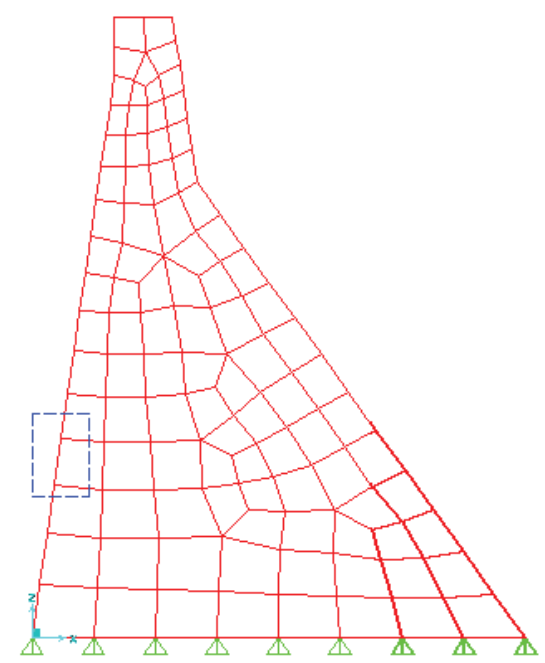

Fig. 5: $Z=15.5 \mathrm{~m}, X=2.26 \mathrm{~m}$, damage severity $50 \%$ (not to scale).

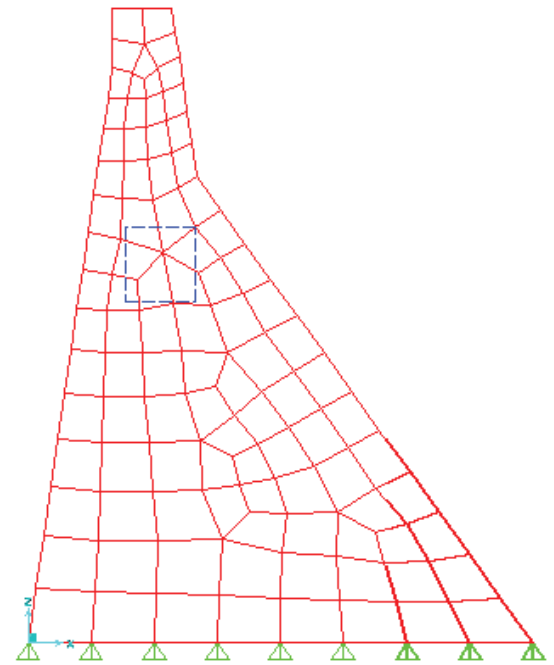

Fig. 6 : $Z=32.5 \mathrm{~m}, X=9.5 \mathrm{~m}$, damage severity $20 \%$ (not to scale).

\subsection{Schematics of the Folsom Dam Scenarios:}

In the Folsom Dam, the damage is shown in the form of $50 \%$ and $20 \%$ reduction of concrete elasticity modulus in two areas with predetermined X and Z (In SAP2000, Z indicates the vertical axis). These locations are shown by a square in the following figures. 


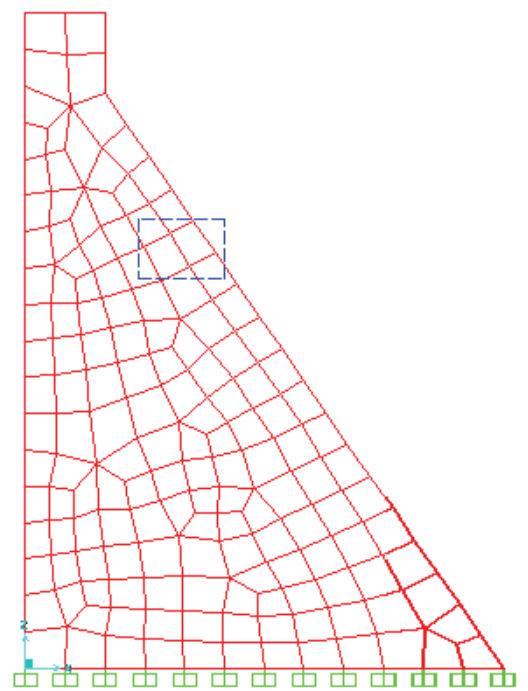

Fig. 7: $Z=53 \mathrm{~m}, X=19 \mathrm{~m}$, damage severity $50 \%$ (not to scale).

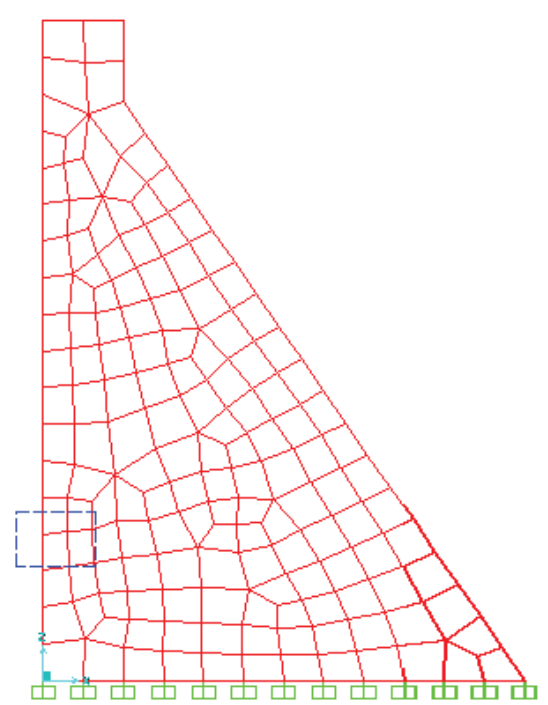

Fig. 8: $Z=20 \mathrm{~m}, X=0 \mathrm{~m}$, damage severity $20 \%$ (not to scale)

\section{MATHEMATICAL DEFINITION OF WAVELET}

The word wavelet denotes a small and transient wave. Its function has two features: being fluctuating and short-term. $\psi(x)$ is the wavelet function only if its Fourier transformation $\psi(x)$ meets the following condition:

$$
\int_{-\infty}^{+\infty} \frac{|\psi(\omega)|}{|\omega|^{2}} d \omega<+\infty
$$

where $\psi(\omega)$ presents $\psi(x)$ Fourier transform, which is defined as $\int_{-\infty}^{+\infty} \psi(x) e^{-i \omega x} d x$ and $\omega$ is the variable of the frequency domain. This condition is known as Admissibility for the $\psi(x)$ wavelet. For the wavelet to have the abovementioned condition, the following equation should be correct:

$$
\psi(0)=\int_{-\infty}^{+\infty} \psi(x) d x=0
$$

In fact, this equation expresses that, for a function to have the wavelet transform, it is necessary that the amount of its Fourier transform be equal to zero in zero frequency, which presents the average amount of that function. This feature of the function with an average of zero is not limiting and, therefore, many functions can be defined as waveletbased. $\psi(x)$ is the mother wavelet function and the used functions in the processing will change in size and location by the two mathematical operations of transmission and scaling in the length of the processed signal.

$$
\psi_{a, b}(x)=\frac{1}{\sqrt{a}} \psi\left(\frac{x-b}{a}\right)
$$

Finally, the wavelet coefficient in each point of signal $b$ and each amount of scale $a$ is calculated as follows: 


$$
\begin{aligned}
& W T(a, b)=W f(a, b)=\frac{1}{\sqrt{a}} \int_{-\infty}^{+\infty} f(x) \psi \\
& \left(\frac{x-b}{a}\right) d x=\int_{-\infty}^{+\infty} f(x) \psi_{a, b}(x) d x
\end{aligned}
$$

To convert a scale to a frequency, the following equation can be used:

$$
F_{a}=\frac{F_{c}}{a \cdot \Delta}
$$

Where, $F_{a}$ is the corresponding frequency to scale $a, F_{c}$ is the main frequency of each wavelet function (the central frequency of which is called wavelet) and $\Delta$ is the sampling period.

But, in the wavelet transformation, when using a function, the vanishing feature of its moments is of great importance. The $K_{t h}$ moment of a $\psi(x)$ wavelet is:

$$
\int_{-\infty}^{+\infty} x^{k} \psi(x) d x=0
$$

Therefore, this wavelet has $M$ vanishing moments (VM) if the following equation is true:

$$
\int_{-\infty}^{+\infty} x^{k} \psi(x) d x=0 \quad \mathrm{k}=0,1,2, \ldots, \mathrm{m}-1
$$

It can be concluded from this equation that each wavelet function has at least one vanishing moment.

In signal processing, another form of WT called Discrete Wavelet Transform (DWT) is also used. In DWT, transformation and scale parameters are chosen discontinuously so that:

$$
a=2^{-j}, b=2^{-j} k
$$

where $j$ and $k$ are integers. As a result, with the substitution for $a$ and $b$, there is:

$$
\psi_{j, k}(x)=2^{j / 2} \psi\left(2^{j} x-k\right)
$$

Considering the defining equation of a wavelet function, it can be determined that there are several functions with these features:

\subsection{Haar Wavelet Function:}

Haar wavelet function is one of the simplest and first wavelets as follows:

$$
\psi(x)=\left\{\begin{array}{l}
1 \Rightarrow \text { for } 0 \leq x<0.5 \\
-1 \Rightarrow \text { for } 0.5 \leq x<1 \\
0 \Rightarrow \text { otherwise }
\end{array}\right.
$$

\subsection{Morelet Wavelet Function:}

Morelet wavelet function is defined as follows: 


$$
\psi(x)=\exp \left(i \omega_{0} x\right) \exp \left(-x^{2} / 2 \sigma^{2}\right)
$$

The domain of the function is normalized. Thus, $\psi(0)=1$ and $\sigma$ is the measure of time expansion $[23,24]$.

\section{RESULTS AND DISCUSSIONS}

\subsection{Analysis of the Intact Dam by Wavelet}

After dam analysis by SAP2000 software, the results obtained are used for wavelet analysis in MATLAB and in the special toolbox for the wavelet. In the width $\left(U_{1}\right)$ and in the length of the dam $\left(U_{2}\right)$, the frequencies are extracted in the first two vibrational modes and in 80 points of the intact dam with equal distances. These frequency responses are analysed by different kinds of wavelets in various scales.

\subsection{Analysis of the Damaged Dam by Wavelet}

Similarly, after dam modelling and destruction by SAP2000, the results of the damaged case, i.e. frequencies in the width $\left(U_{1}\right)$ and in the length $\left(U_{2}\right)$ of the dam, are extracted for the first two vibrational modes and in 80 points of the intact dam in the crest elevation with equal distances. This response is analysed by MATLAB in the special toolbox for the wavelet with various kinds of wavelets (5 kinds of MATLAB toolbox wavelets) whose results are presented in the following figures. As shown, the graphs include a noticeable variation in the location of the damage in the dam, while there is no sudden turbulence or discontinuity in the graphs in the case of an intact dam. In other words, the location of the damage is assumed in different places in the body of the dam as was shown in Fig.3-8 with regards to the figures, the turbulence is practically situated in the location of the damage in the dam. Using the wavelet transformation for locating the damage depends on features which make SWT distinctive in comparison with other methods. As geometrical changes cause a variation in wavelet coefficients, the results of the direct signal wavelet cannot be solely relied on. As a result, the difference between the intact and damaged structure modal shapes has been used in addition to the above criterion.

In both intact and damaged cases, the wavelet transform implementation has been done in MATLAB software as it is one of the most powerful tools for processing and analysing the results. In the following figures, the responses of the intact and damaged dams and differences in modal shapes between the intact and damaged dams are illustrated in $U_{1}$ and $U_{2}$ directions based on different wavelets. It should be noted that, due to the article length limitations, only some of the figures have been chosen and presented. In addition, the red circles in the figures show turbulence in the structures.

A set of frequencies, which is performed over a short time period in a signal can be identical with a set in another time. This signal is called static. It should be mentioned that $\mathrm{X}$ and $\mathrm{Z}$ coordinates in the simulated figures are recorded in meters and the base of the coordinates is at the lower bottom point and the numbers of the nodes are from bottom to top in a way that the crest of the dam contains nodes with higher numbers. Moreover, the $\mathrm{X}$-axis is the number of nodes in the structure ( 80 nodes in total) and the Y-axis shows the amplitude of DWT coefficients. It should be noted that although this paper's experimental values have been considered for $\alpha$ and $\beta$ parameters in simulations, they can be 
favourably chosen to observe different aspects of the wavelet transform. In addition, the location of the damage in both $\mathrm{X}$ and $\mathrm{Z}$ dimensions is selected arbitrarily in each simulation.

\subsection{The Pine Flat Dam Results:}

According to Eq. (2) and (3), Rayleigh damping coefficients of the dam are considered as the following:

$$
\begin{aligned}
& \alpha=1.8511 \\
& \beta=0.001049
\end{aligned}
$$

As it was stated before, the wavelet transform has been characterized in multiple frequency modes where different features of the input measurements can be observed in each mode. Based on this, in order to track the behaviour of the wavelet transform in each frequency mode, the frequency of the different modes is proposed in a table for each scenario. It should be noted that four different frequency bands have been considered in the simulations and the results of each scenario are shown in the following table. However, to determine the damage in each scenario, the amplitudes of DWT coefficients of mode shape differentiation, according to frequencies, between the intact and damaged dams should be extracted.

Scenario 1: Damage in the location of $Z=63 \mathrm{~m}, X=36 \mathrm{~m}$ and damage severity $50 \%$ :

Table 2: DWT frequency results of Scenario 1

\begin{tabular}{ccccc}
\hline Case & $\begin{array}{c}\text { First Mode } \\
\text { Frequency }\end{array}$ & $\begin{array}{c}\text { Second Mode } \\
\text { Frequency }\end{array}$ & $\begin{array}{c}\text { Third Mode } \\
\text { Frequency }\end{array}$ & $\begin{array}{c}\text { Fourth Mode } \\
\text { Frequency }\end{array}$ \\
\hline Intact & 4.00239 & 7.87459 & 11.16418 & 13.90654 \\
Damaged & 3.82147 & 7.54841 & 10.94523 & 13.21456 \\
\hline
\end{tabular}

The variations in DWT mode shapes show differences in mode shape changes of the two mentioned data sets. In fact, the presence of destruction in a structure alters the observations derived from the structure and, consequently, results in the variation of the frequency content and mode shapes. In the following figures, the red circles show turbulence, i.e., destruction. In other words, the red circles represent the location of the DWT variation and therefore, the location of destruction in the dam's height. In each figure, there are 5 curves related to 5 different coefficients of the DWT extracted by MATLAB toolbox. It should be noted that the MATLAB toolbox basically calculates 5 different DWT coefficients which correspond to 5 different frequency bands. Furthermore, each frequency band contains different sets of information about the input data in a way that the first and the fifth coefficients correspond to the lowest-rate and highest-rate spatial variations, respectively. In addition, since the structural destructions appear as a high-rate variation in the observations, the fifth coefficient of the DWT is more reasonable for detecting the existence of the damage and also extracting its location. Based on this, in each scenario, the position of the significant variation in the fifth figure is utilized in order to locate destruction in the structure. In the figures below, the $\mathrm{X}$-axis presents 80 nodes in the height of the dams. For instance, the Pine Flat Dam is $130 \mathrm{~m}$ high. The damage in the height of $Z=63 \mathrm{~m}$ is equal to Node 39 in 80 nodes in the height of the dam.

Note that the curves in Fig. 9 and Fig. 10, which illustrate the amplitudes of the DWT coefficients of the mode shapes for the intact and damaged dams respectively, multiple amplitude variations are visible in each curve and, therefore, the destruction cannot be 
easily detected from the mentioned figures. Clearly, the damage should be detected from the difference of the intact and damaged observations, the DWT coefficients of which are depicted in Fig. 11.

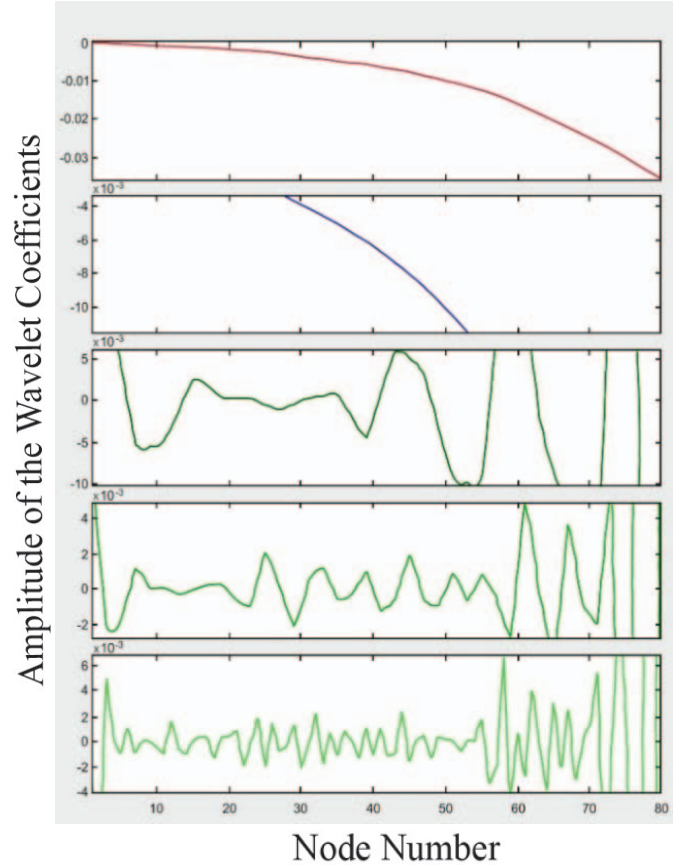

Fig. 9: Intact dam under DWT.

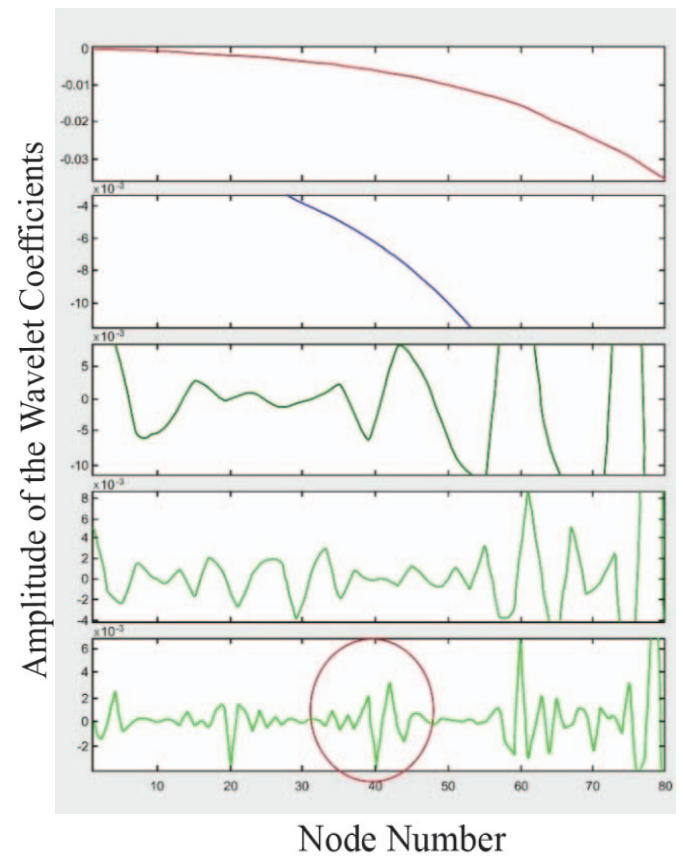

Fig. 10: Damaged dam under DWT.

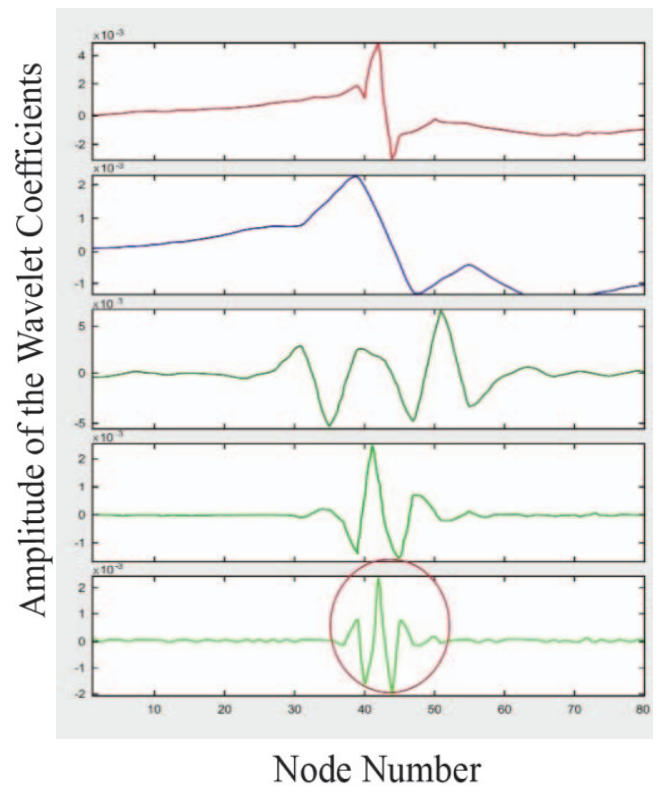

Fig. 11: Shape Mode Differentiation between the intact and damaged dam under DWT.

Figure 11 illustrates the amplitudes of the DWT coefficients of mode shape differentiation between the intact and damaged dams. In this figure, the change in the amplitude of DWT coefficients is clear and the existence of damage can be detected. In all scenarios, the curves of shape mode differentiations between the intact and damaged dams under DWT are the best choices for clarification of destruction's existence in the structure and also detecting its location (in the height). This is observable in different simulation results because, in contrary to the damaged dam, which may exhibit multiple amplitude 
variations, the DWT of mode shape differentiation represents a single and significant amplitude variation. Moreover, it can be seen that the position of this amplitude variation is along the height of damage. Based on multiple simulations, the severity of the variation in DWT coefficients corresponds to that of destruction.

Scenario 2: Damage in the location of $Z=30 \mathrm{~m}, X=1.5 \mathrm{~m}$ and damage severity $20 \%$ :

Table 3: DWT frequency results of Scenario 2

\begin{tabular}{ccccc}
\hline Case & $\begin{array}{c}\text { First Mode } \\
\text { Frequency }\end{array}$ & $\begin{array}{c}\text { Second Mode } \\
\text { Frequency }\end{array}$ & $\begin{array}{c}\text { Third Mode } \\
\text { Frequency }\end{array}$ & $\begin{array}{c}\text { Fourth Mode } \\
\text { Frequency }\end{array}$ \\
\hline Intact & 4.00239 & 7.87459 & 11.16418 & 13.90654 \\
Damaged & 3.92446 & 7.54521 & 10.98659 & 13.32436 \\
\hline
\end{tabular}

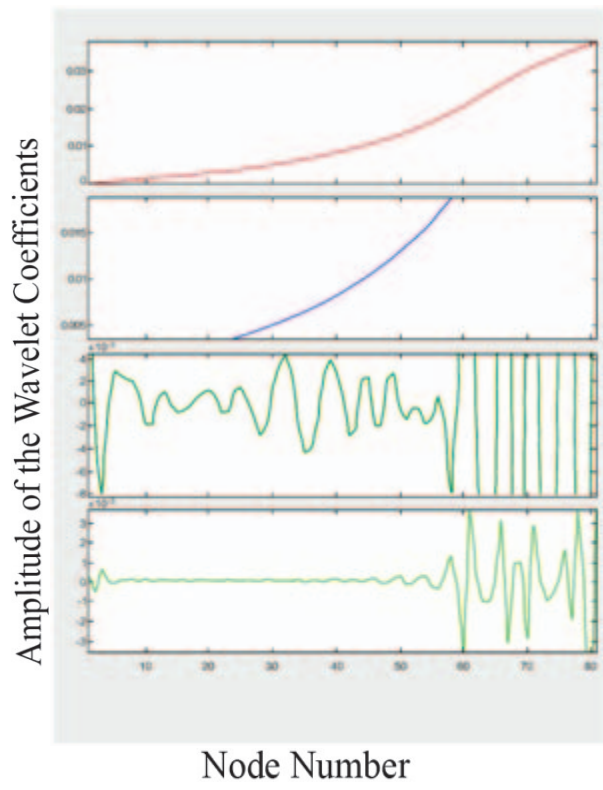

Fig. 12: Intact dam under DWT.

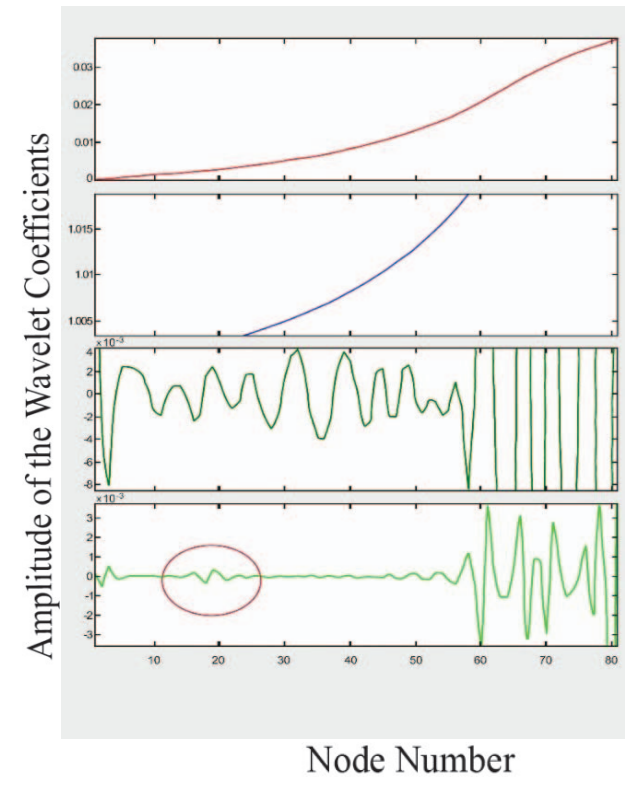

Fig. 13: Damaged dam under DWT.

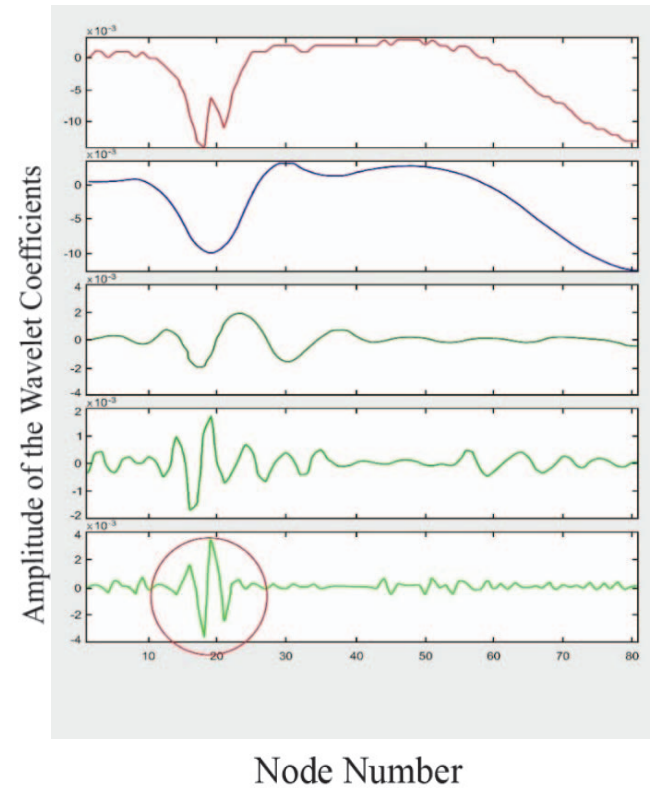

Fig. 14: Shape Mode Differentiation between the intact and damaged dam under DWT. 


\subsection{The Bluestone Dam Results:}

Similar to the former case, based on Eq. (2) and (3), Rayleigh damping coefficients in this structure are:

$$
\begin{aligned}
& \alpha=3.6519 \\
& \beta=0.000529
\end{aligned}
$$

Scenario 1: Damage in the location of $Z=15.5 \mathrm{~m}, X=2.26 \mathrm{~m}$ and damage severity $50 \%$ :

Table 4: DWT frequency results of Scenario 1

\begin{tabular}{ccccc}
\hline Case & $\begin{array}{c}\text { First Mode } \\
\text { Frequency }\end{array}$ & $\begin{array}{c}\text { Second Mode } \\
\text { Frequency }\end{array}$ & $\begin{array}{c}\text { Third Mode } \\
\text { Frequency }\end{array}$ & $\begin{array}{c}\text { Fourth Mode } \\
\text { Frequency }\end{array}$ \\
\hline Intact & 7.87192 & 16.43285 & 22.21290 & 29.25511 \\
Damaged & 7.69217 & 16.01366 & 22.02352 & 28.7135 \\
\hline
\end{tabular}

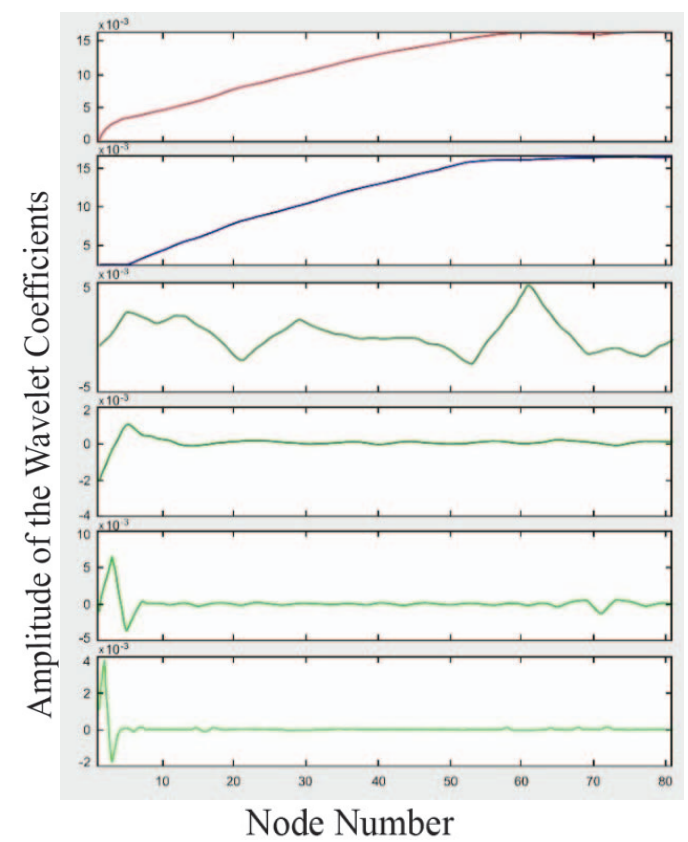

Fig. 15: Intact Dam under DWT

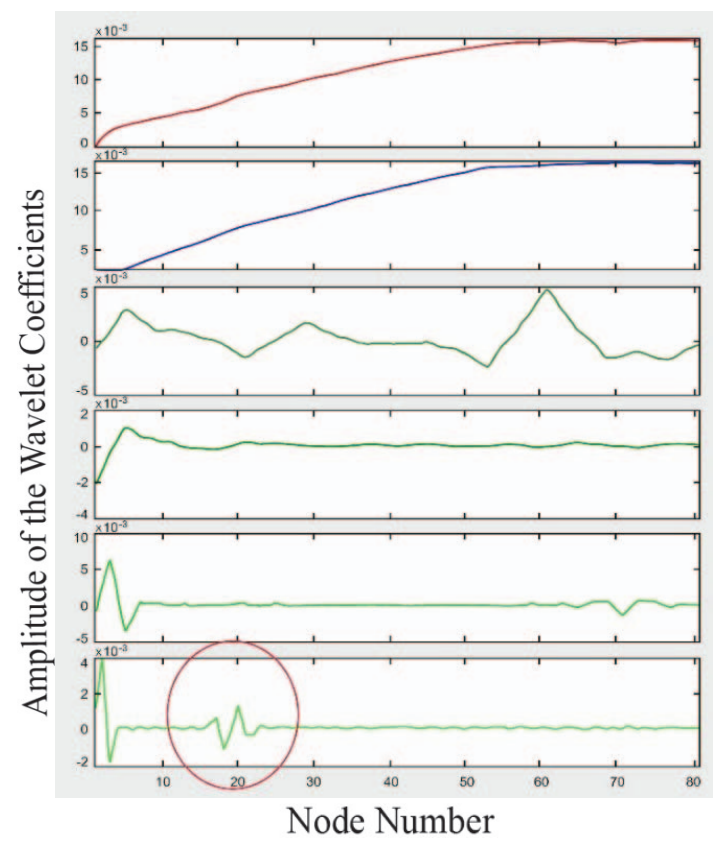

Fig. 16: Damaged Dam under DWT.

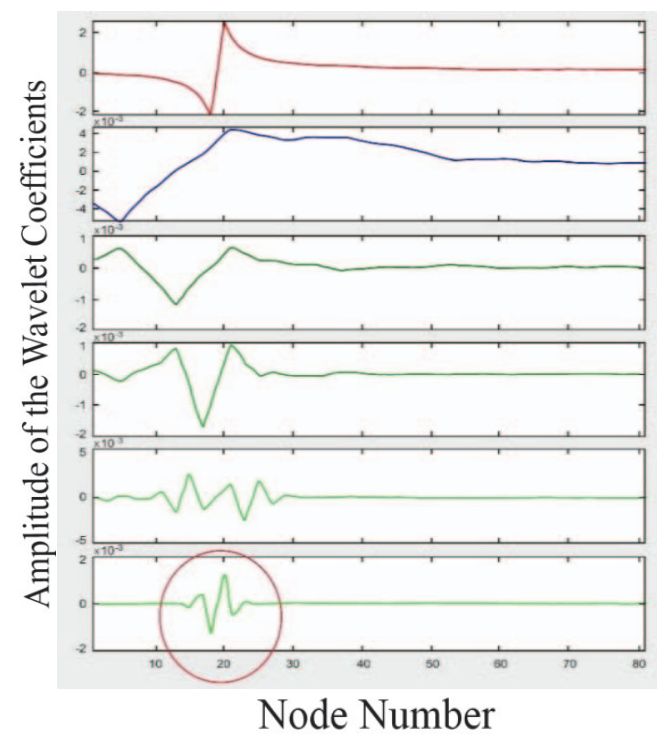

Fig. 17: Shape Mode Differentiation between the intact and damaged dam under DWT. 
Scenario 2: Damage in the location of $Z=32.5 \mathrm{~m}, X=9.5 \mathrm{~m}$ and damage severity $20 \%$ :

Table 5: DWT frequency results of Scenario 2

\begin{tabular}{ccccc}
\hline Case & $\begin{array}{c}\text { First Mode } \\
\text { Frequency }\end{array}$ & $\begin{array}{c}\text { Second Mode } \\
\text { Frequency }\end{array}$ & $\begin{array}{c}\text { Third Mode } \\
\text { Frequency }\end{array}$ & $\begin{array}{c}\text { Fourth Mode } \\
\text { Frequency }\end{array}$ \\
\hline Intact & 7.87192 & 16.43285 & 22.21290 & 29.25511 \\
Damaged & 7.790436 & 15.90344 & 21.89885 & 28.15104 \\
\hline
\end{tabular}

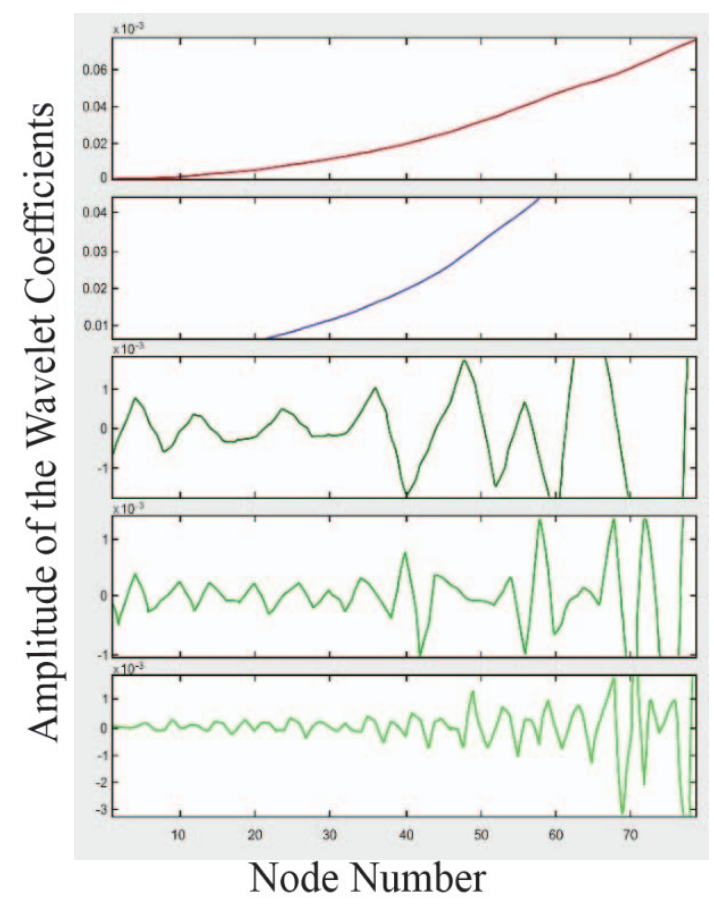

Fig. 18: Intact dam under DWT.

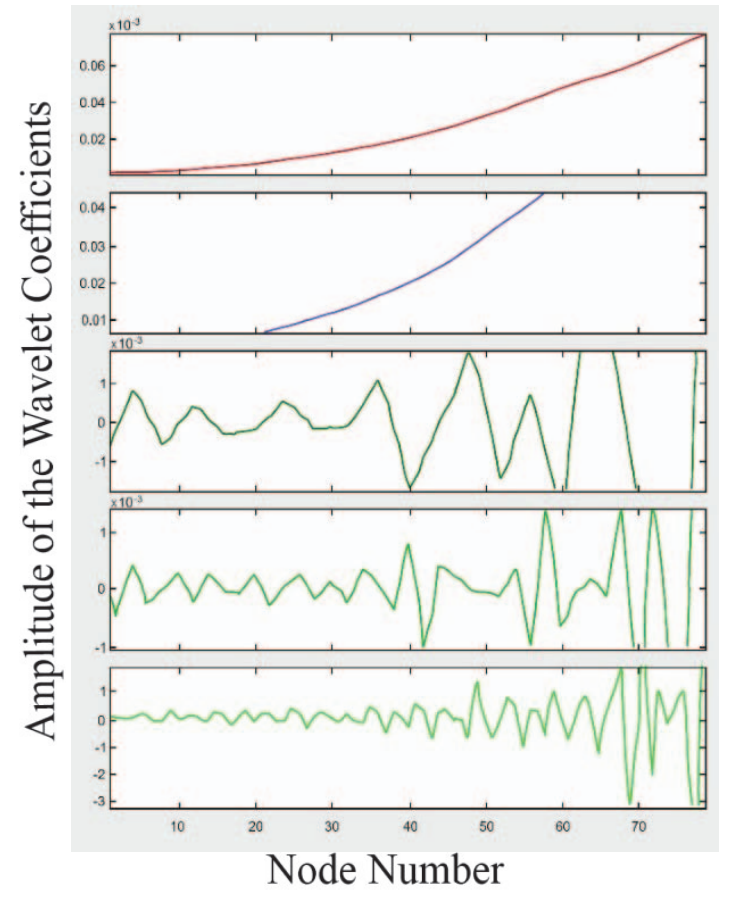

Fig. 19: Damaged dam under DWT.

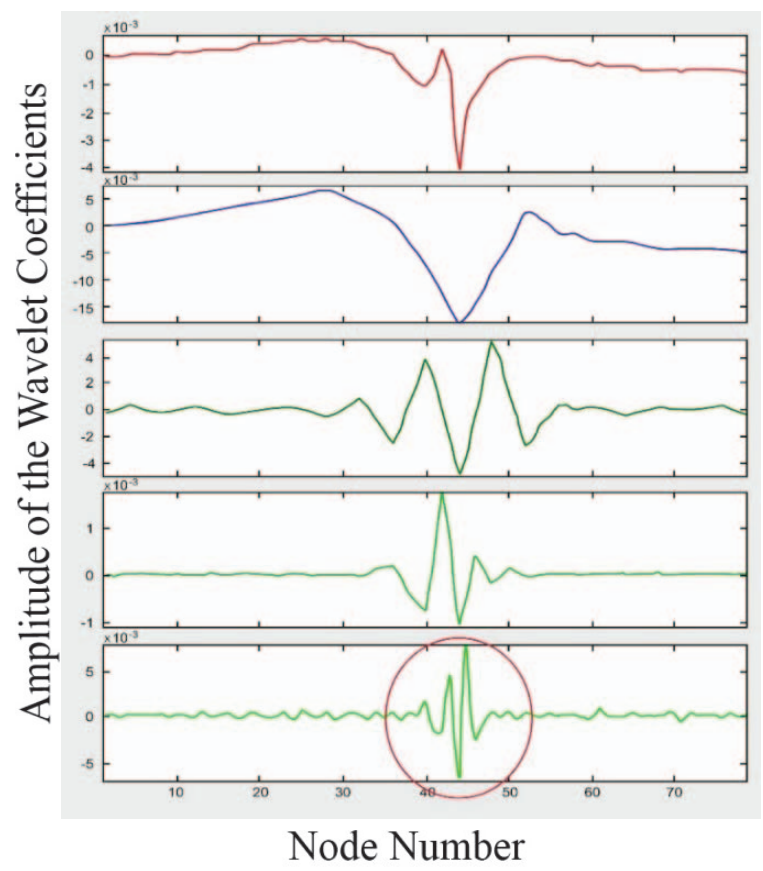

Fig. 20: Shape Mode Differentiation between the intact and damaged dam under DWT. 
In Figs. 18-20, it is evident that due to the low severity of damage, the wavelet coefficients did not change and showed no damage in the first mode. As a result, only the shape mode differentiation criterion is used.

\subsection{The Folsom Dam Results:}

Finally, for the last model, Rayleigh damping coefficients can be computed by Eq. (2) and (3) as below:

$\alpha=2.3168$

$\beta=0.000835$

Scenario 1: Damage in the location of $Z=53 \mathrm{~m}, X=19 \mathrm{~m}$ and damage severity $50 \%$ :

Table 6: DWT frequency results of Scenario 1

\begin{tabular}{ccccc}
\hline Case & $\begin{array}{c}\text { First Mode } \\
\text { Frequency }\end{array}$ & $\begin{array}{c}\text { Second Mode } \\
\text { Frequency }\end{array}$ & $\begin{array}{c}\text { Third Mode } \\
\text { Frequency }\end{array}$ & $\begin{array}{c}\text { Fourth Mode } \\
\text { Frequency }\end{array}$ \\
\hline Intact & 4.99753 & 11.85027 & 14.63031 & 20.90755 \\
Damaged & 4.91682 & 11.70903 & 14.55132 & 20.70476 \\
\hline
\end{tabular}

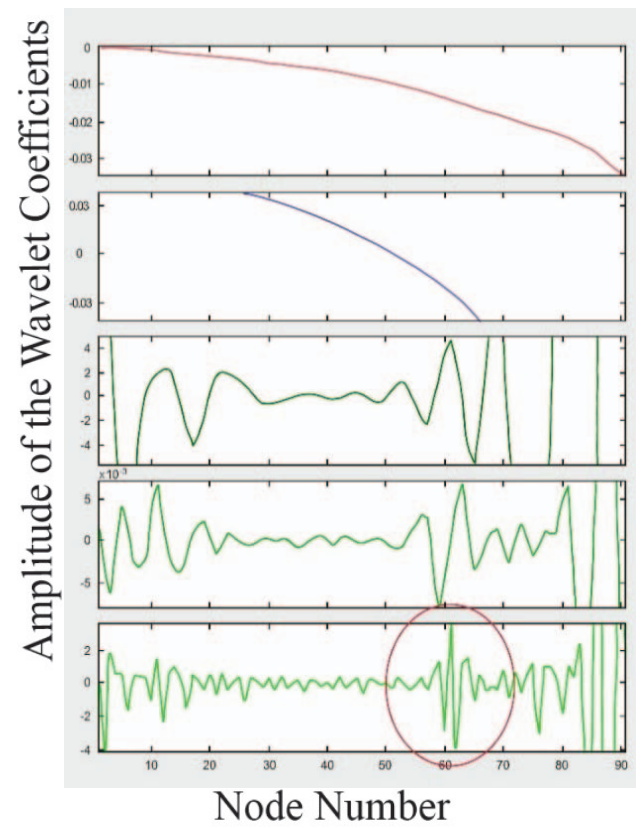

Fig. 21: Intact dam under DWT.

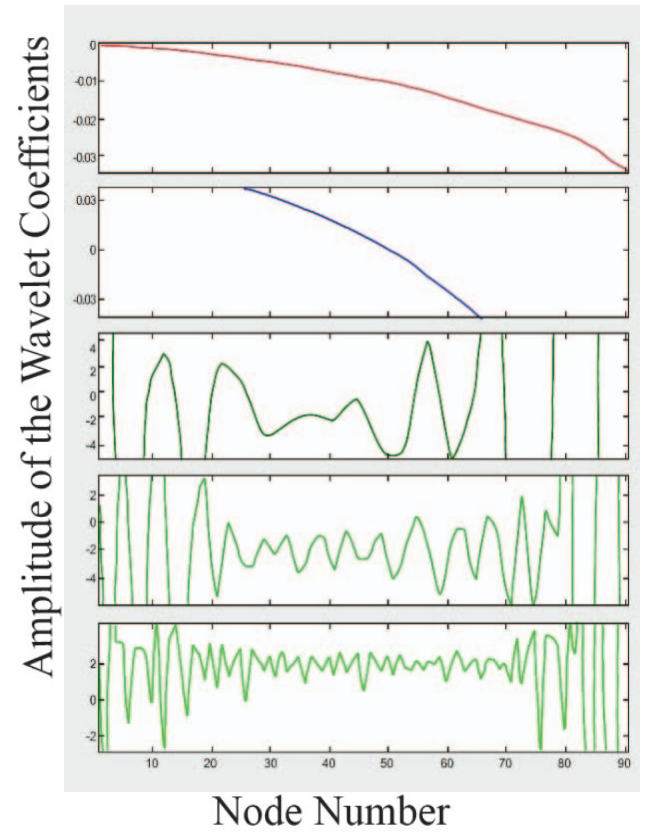

Fig. 22: Damaged dam under DWT. 


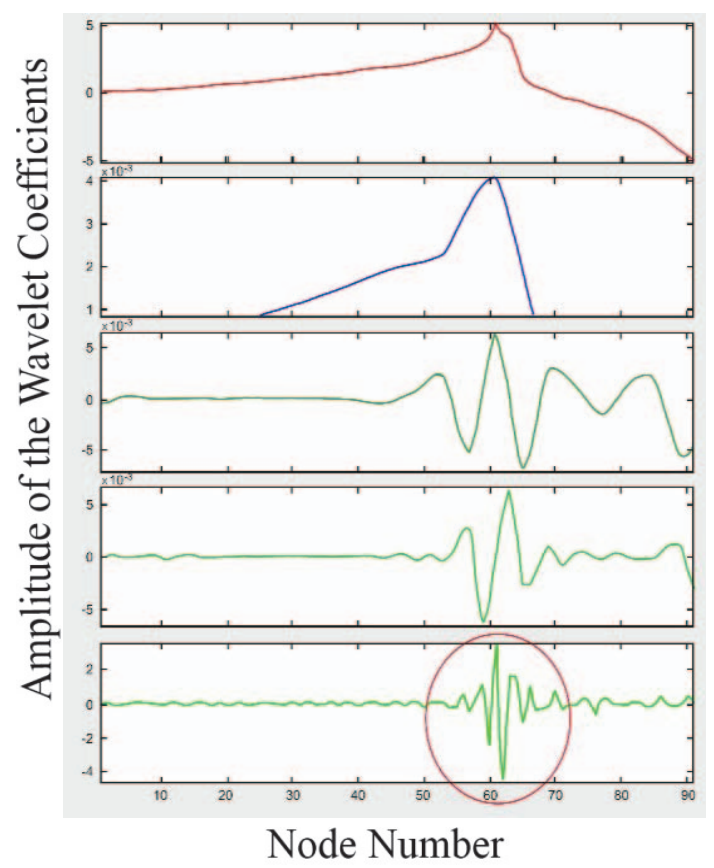

Fig. 23: Shape Mode Differentiation between the intact and damaged dam under DWT.

Scenario 2: Damage in the location of $Z=20 \mathrm{~m}, X=0 \mathrm{~m}$ and damage severity $20 \%$ :

Table 7: DWT frequency results of Scenario 2

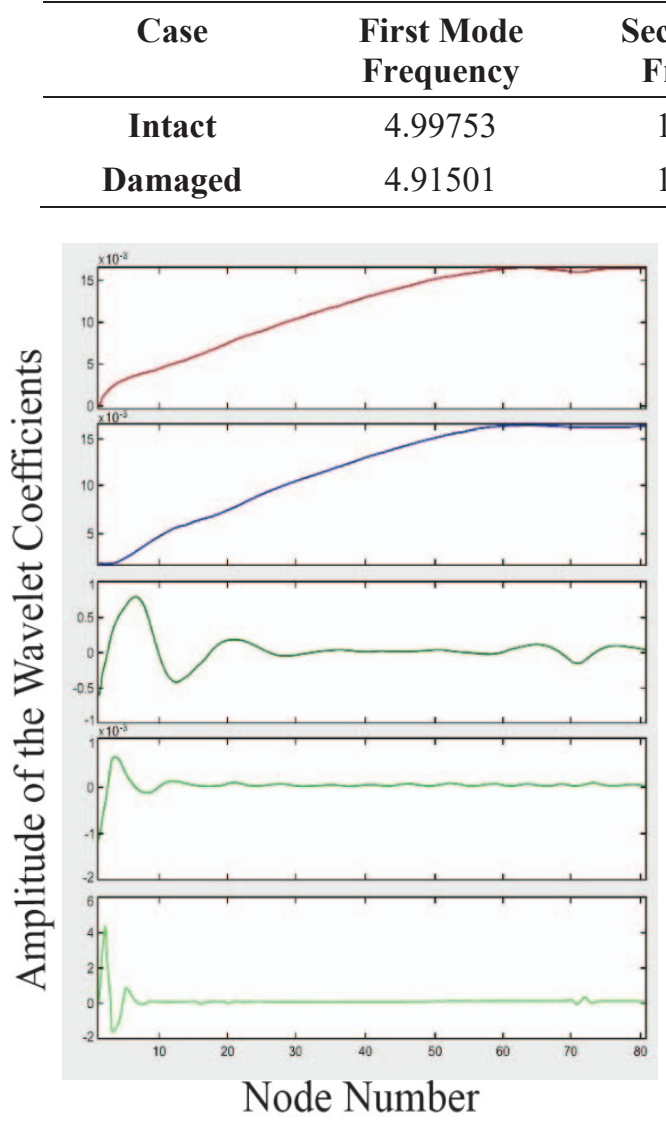

Fig. 24: Intact Dam under DWT.

\begin{tabular}{ccc}
$\begin{array}{c}\text { Second Mode } \\
\text { Frequency }\end{array}$ & $\begin{array}{c}\text { Third Mode } \\
\text { Frequency }\end{array}$ & $\begin{array}{c}\text { Fourth Mode } \\
\text { Frequency }\end{array}$ \\
\hline 11.85027 & 14.63031 & 20.90755 \\
11.46838 & 14.46838 & 20.29696 \\
\hline
\end{tabular}

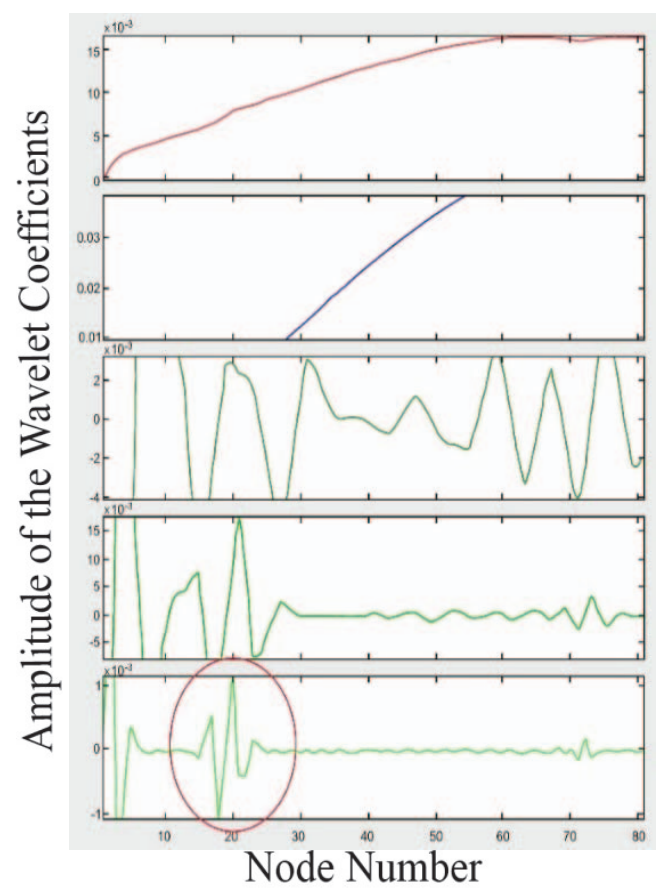

Fig. 25: Damaged dam under DWT. 


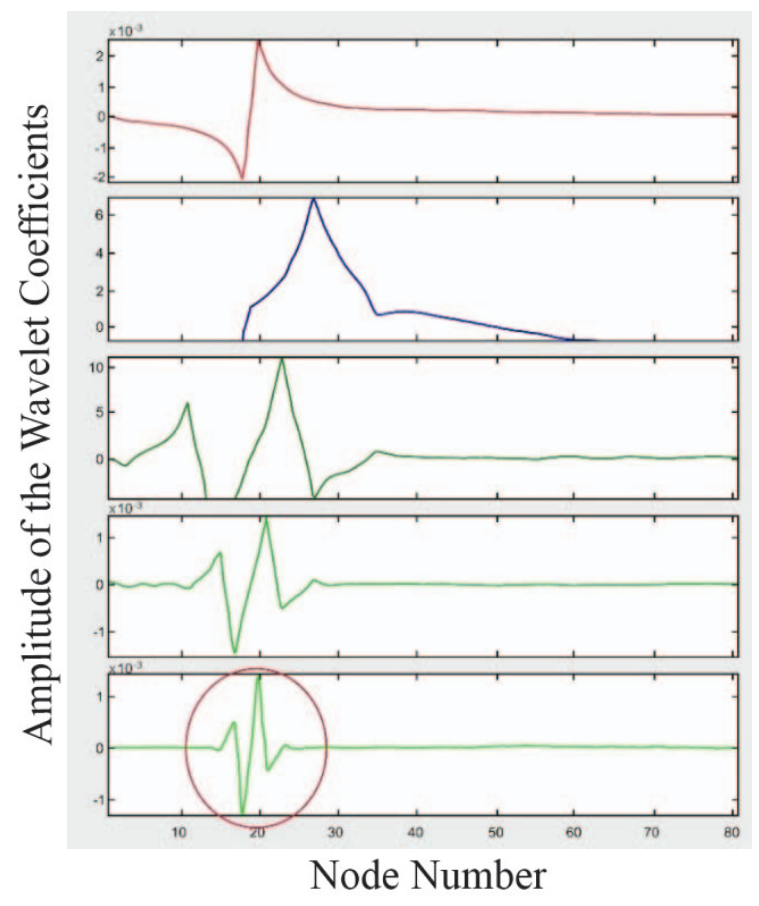

Fig. 26: Shape Mode Differentiation between the intact and damaged dam under DWT.

\section{CONCLUSION}

In this article, the well-known Folsom, Pine Flat, and Bluestone dams were selected. After reduction of the elasticity modulus by $20 \%, 30 \%$ and $50 \%$, the frequencies were obtained from the first four modes for intact and damaged cases. Modal analysis was done by SAP2000. Then through wavelet analysis in MATLAB toolbox, damage detection was investigated.

As it was seen, the wavelet transform has a high capability in processing the static or dynamic response signal. This capability is manifest in the identification of various kinds of discontinuity or disharmony, such as sudden reduction of stiffness. This can be identified from the continuous wavelet coefficient graph as one or some points close to one another and showing turbulence or quantities being disharmonious with the other points. As a result, the wavelet method is one of the most effective approaches in the field of damage detection, which has already been ignored.

The amplitude of DWT curves for the amounts of modal shapes of the damaged dam in comparison with the intact one showed a noticeable variation, the intensity of which was proportionate with the severity of damage in the structure. In higher frequencies, damage in the structure was more evident since the gradient vector was in the same direction with damage. Therefore, the surge range of the wavelet coefficient corresponding to a higher frequency was more intense than the other coefficients.

Geometric changes in the structure resulted in a change in wavelet coefficients. Thus, in the present article, in addition to the behavioural investigation of DWT in the damaged case, DWT behaviour was also assessed for differences in data related to the intact and damaged conditions. As it was seen before, damage detection in the structure through DWT coefficient curves of data differences for the intact and damaged cases was better than just the damaged case.

The location of variation in the amplitude of DWT coefficients defined damage in the dam based on the number of the node (along the height). This result was of great 
significance because determining the location of damage causes improvement and facilitates the process of restoration. It should also be noted that as the observations were measured according to different nodes, the accuracy of damage detection was equal to the length of each node along the height.

Finally, as it can be inferred from this article, primary damage detection in dams and proper investigation can prevent the progress of destruction and fatal consequences. In other words, using the technique presented in this study, one can effectively determine the location and severity of damage in concrete gravity dams without any destructive effects. In addition, researchers and engineers can employ this approach to maintain and retrofit these important infrastructures.

\section{REFERENCES}

[1] Dhakal D, Neupane K, Thapa C, Ramanjaneyulu G. V. (2013) Different techniques of structural of health monitoring. International Journal of Civil Structural Environmental and Infrastructure Engineering, 3(2): 55-66.

[2] Aldemir A, Binici B, Arici Y, Kurc O, Canbay E. (2015) Pseudo-dynamic testing of a concrete gravity dam. Earthquake Engineering Structural Dynamics, 44(11): 1747-1763. https://doi.org/10.1002/eqe.2553.

[3] Alembagheri, M, Ghaemian M. (2013) Damage assessment of a concrete arch dam through nonlinear incremental dynamic analysis. Soil Dynamics and Earthquake Engineering, 44:127-137. http://dx.doi.org/10.1016/j.soildyn.2012.09.010.

[4] Raich AM, Liszkai TR. (2012) Multi-objective optimization of sensor and excitation layouts for frequency response function-based structural damage identification. Computer-Aided Civil and Infrastructure Engineering, 27(2): 95-117. https://doi.org/10.1111/j.14678667.2011.00726.x.

[5] Lian J, He L, Ma B, Li H, Peng W. (2013). Optimal sensor placement for large structures using the nearest neighbor index and a hybrid swarm intelligence algorithm. Smart Materials and Structures, 22(9): 82-92. https://doi.org/10.1088/0964-1726/22/9/095015.

[6] Pirboudaghi S, Tarinejad R, Alami M. (2016). Damage detection based on system identification of concrete arch dam using XFEM based cohesive crack segments and wavelet transform. Modarres Mechanical Engineering Journal, 16(12): 373-383.

[7] Lin C. (2016). Ambient modal identification using non-stationary. Archive of Applied Mechanics, 86(8):1449-1464.

[8] Chiu JK, Cermak JE, Chou LS. (2007). Random decrement based method for modal parameter identification of a dynamic system using acceleration responses. Journal of Wind Engineering and Industrial Aerodynamics, 95(6): 389-410. https://doi.org/10.1016/j.jweia.2006.08.004.

[9] Sun D, Ren Q. (2016). Seismic damage analysis of concrete gravity dam based on wavelet transform. Shock and Vibration, 9: 1-8. http://dx.doi.org/10.1155/2016/6841836.

[10] Samii A, Lotfi V. (2007). Comparison of coupled and decoupled modal approaches in the seismic analysis of concrete gravity dams in the time domain. Finite Elements in Analysis and Design, 43:1003-1012. https://doi.org/10.1016/j.finel.2007.06.015.

[11] Calayir Y, Dumanoğlu AA, Bayraktar A. (2007). Earthquake analysis of gravity damreservoir systems using the Eulerian and Lagrangian approaches. Computers \& Structures, 5(3): 877-890. https://doi.org/10.1016/0045-7949(95)00309-6.

[12] SAP2000, C. S. I. (2015). Computer \& Structures Inc. Linear and nonlinear static and dynamic analysis of three-dimensional structures. Berkeley (CA): Computer \& Structures.

[13] Pirboudaghi S, Tarinejad R, Alami M. (2018). Damage detection based on system identification of concrete dams using an extended finite element-wavelet transform coupled procedure. Journal of Vibration and Control, 24(18): 4226-4246.

https://doi.org/10.1177/1077546317722428 
[14] Kourehli SS. (2018). Structural damage identification based on expanded mode shapes using extreme learning machine. Sharif Journal of Civil Engineering, 33(2): 91-98.

[15] Hariri-Ardebili MA, Saouma VE. (2016). Collapse fragility curves for concrete dams: a comprehensive study. Journal of Structural Engineering, 142(10): 374-399. doi: 10.1016/j.engstruct.2016.09.034.

[16] USACE. (1995) Gravity dam design. US Army Corps of Engineers, USA.

[17] Ellingwood B, Tekie P. (2003). Fragility analysis of concrete gravity dams, USA.

[18] Alembagheri M, Seyedkazemi M. (2014). Seismic performance sensitivity and uncertainty analysis of gravity dams. Earthquake Engineering Structural Dynamics, 44(1): 41-58. https://doi.org/10.1002/eqe.2457.

[19] Yankey G, Deschamps R, McCray M, Bentler DJ. (2000). Parametric study and subsurface exploration plan for Bluestone Dam BT - sessions of geo-Denver 2000 - slope stability 2000, GSP 101, 289: 355-371.

[20] Bayraktar A, Türker T, Akköse M, Ateş Ş. (2010). The effect of reservoir length on seismic performance of gravity dams to near- and far-fault ground motions. Natural Hazards, 52(2): 257-275.

[21] Alembagheri M. (2016). Earthquake damage estimation of concrete arch dams using linear analysis and empirical failure criteria. Soil Dynamics and Earthquake Engineering, 90: 327339.

[22] Lotfollahi M, Shamsaei M, Hesari M. (2011) Using static wavelet transformation (SWT) in crack detection of arch concrete dams under frequency analysis. Omran Modares Journal, 3: 27-39.

[23] Daubechies I. (1992). Ten lectures on Wavelets. CBMS-NSF Conference Series 61, Philadelphia, PA: SIAM. https://doi.org/10.1137/1.9781611970104.

[24] Mallat SG. (1999). A Wavelet Tour of Signal Processing, London: Academic Press. PMCid:PMC407895, 2nd Ed. 